\title{
THE ROLE OF NOTARY IN DEED OF SALE AND PURCHACE AGREEMENT TO SUPPORT NATIONAL DEVELOPMENT
}

\author{
Hasyim Mustofa \\ Lawyer, Semarang, Central Java, Indonesia \\ HasyimMustofa999@gmail.com
}

\begin{abstract}
Notary's duty is as a legal profession carrier in the making of Land sale and purchase Deed as a perfect proof. However, the Notary in carrying out his duties and authorities must pay attention to the formal and material aspects. In this case, there are some constraints such as the status of land and the Notary is not authorized to run a Position outside his/her position. Method approach used in this study was normative juridical, where the data source comes from secondary data, consisting of primary, secondary and tertiary legal materials. The results of the research found that the role of notary in making the deed of land purchase agreement to support the national development rests with the legal relationship to bind the parties' engagement in the form of the PPJB (Sale and Purchase Binding Agreement) deed which can be used as the perfect evidence when one of the parties pledges through the lawsuit in the court. As well as obstacles in making the Deed PPJB include land status, such the status of customary land, State land and land letter $\mathrm{C}$ so as to violate the object of agreement as regulated in Article 1320 Civil Code. Furthermore, the unauthorized acts are as referred to in Article 85 of the Notary Position Law.
\end{abstract}

Keywords: Role of Notary, Sale and Purchase Agreement, National Development.

\section{A. INTRODUCTION}

The policy in land affairs shall be sourced from the spirit of Article 33 of the 1945 Constitution, which affirms that "Earth, Water and Natural Property contained therein shall be controlled by the state for the greatest prosperity of the people". This norm is then poured explicitly in Law no. 5 of 1960 on Basic Agrarian Law (UUPA) where in Article 2 paragraph (1), it states that based on the provisions of Article 33 Paragraph (3) of the 1945 Constitution and the matters referred to in Article 1 in which the earth, water and space including the natural wealth contained in it is at the highest level controlled by the state as an organization of power of all people. ${ }^{1}$

It is inevitable that the need for land is a basic necessity that must be owned by everyone. There is even an expression of local wisdom which confirms that "Sakdhumuk batok senyari bumi, yen perlu ditohi pati" or "ango' apoteya

\footnotetext{
Nia Kurniati, 2012, Laporan Akhir Tim Pengkajian Hukum Tentang Pengelolaan Tanah Negara Bagi Kesejahteraan Rakyat, Pusat Penelitian dan Pengembangan Sistem Hukum Nasional Badan Pembinaan Hukum Nasional Kementerian Hukum dan Hak Asasi Manusia RI, Jakarta, page1.
}

tolang ebanding apoteya mata" atau "ulos na so boi maribak". Generally, these three phrases mean the placement and function of the land that has a sacred value for human life, if necessary people should sacrifice lives in order to maintain the land. ${ }^{2}$

According to Bernard Limbong, land as part of the surface of the earth has significance in human life, either as a place or space for life with all its activities, as a source of life, even a nation, the land is an element of territory in the sovereignty of the state. ${ }^{3}$ Inevitably, as described by Budi Harsono regarding the use of land, it should be adapted to the circumstances and the nature of the rights so it benefit the welfare and happiness of the owner at once for the community and the State. Such provision does not imply that the interests of the individual shall be entrusted entirely by the public interest. The interests of society and the interests of individuals

\footnotetext{
2 Nurhasan Ismai, 2012, Arah Politik Hukum Pertanahan dan Perlindungan Tanah Kepemilikan Masyarakat, Jurnal Rechtsvinding, Volume 1 Nomor 1, April 2012, pg. 34

3 Bernhard Limbong, 2012, Hukum Agraria Nasional, Margaretha Pustaka, Jakarta, page243.
} 
must balance each other until it achieves the ultimate goal, namely prosperity, justice and happiness for the people as a whole ${ }^{4}$. This is a reflection to avoid land conflicts that often occur in almost all parts of Indonesia, especially during the economic crisis in 1997-1998 which, according to Darwin Ginting, people's access to land can be said to be too late, due to the implementation of development in the new order period only pursuit of economic growth, this became one of the triggers of community unrest that eventually also encouraged the occurrence of land conflicts. ${ }^{5}$

Conflict and land disputes are the concern of the Government at this time. The government has created a program entitled "The National Strategy on Access to Justice (SNAK) 2016-2019". The main objective to be achieved by the Government in this field is the realization of agrarian justice through the control of the management and utilization of legal and rechtsbeschreming/ legal protection and justice for the society (social justice). Notary' in making deed especially related to land has very central and strategic role, for example Bond of Sale and Purchase Deed, Deed of Sale and Purchase, Deed of Right Release and others. Notary is one of the legal profession bearers (rechtsbeofenaar) by providing legal services that sustain the development process, clearly visible especially in making deed to meet the needs of the community. ${ }^{6}$ In fact, it is not only the judge who is obliged to make legal discovery (rechtsvinding) to solve the concrete problems he faces. According to Sudikno Mertokusumo, the power of legal problem solving of a Notary

4 Boedi Harsono, 2012, Hukum Agraria Indonesia, Djambatan, Bandung, page45.

5 Darwin Ginting, 2010, Hukum Kepemilikan Hak Atas Tanah Bidang Agribisnis, Ghalia Indonesia, Jakarta, 2010, page150.

6 Consideration of Law no. 30 Year 2004 regarding Position of Notary. In addition to Notaries, the legal profession is a lawyer / advocate, judge, and prosecutor. See Article 15 paragraph (2) letter $f$ of Law no. 2 Year 2014 on Amendment to Law no. 30 Year 2004 regarding the Notary's Office reads: "In addition to the authority referred to in paragraph (1), the Notary is also authorized: $f$. make a deed related to land. " is to face the legal problem proposed by his client to make the deed. The notary must find his or her law from the concrete event filed by the client to be made his act. The result of legal discovery by a Notary is a law because it is a deed containing legal norms and has binding power as well as a source of law. ${ }^{7}$

Moving from the legal issues concerning the role of Notary in development especially related to the making of the sale and purchase deed is a legal event. According to Sudikno Mertokusumo, legal events are events relevant to the law. Events which by law are linked by law or events are connected with the emergence of rights and obligations. ${ }^{8}$ Meanwhile, Satjipto Rahardjo defines the legal event is something that moves the rule of law so that this event shows its potential to regulate. ${ }^{9}$ Peter Mahmud Marzuki defines a legal event as an event regulated by law, since those events relate to legal rights and obligations. ${ }^{10}$

The needs of the community cannot be separated from the making of the Notary Deed, it is used to ensure certainty, order and legal protection required authentic written evidence of deeds, agreements, determinations, and legal events made before or by authorized officials, namely Notary. Under Article 1 Sub-Article 7 of the UUJN, the Deed is an authentic deed created by or in the presence of a Notary under the form and ordinance specified in the UUJN. In carrying out his position, Notary one of them has an obligation to act trustful, honest, thorough, independent, impartial, and safeguarding the interests of related parties in legal acts committed by the interlocutors as regulated in Article 16 paragraph (1) letter a UUJN. In other words, it can be withdrawn an adigium that any making of the Deed of Sale and Purchase made before a Notary is an invention of law and legal products.

Based on the background description of

7 Sudikno Mertokusumo, 2014, Penemuan Hukum Sebuah Pengantar, Edisi Revisi, Cahaya Atma Pustaka, Yogyakarta, page51.

8 Sudikno Mertokusumo, 2003, Mengenal Hukum Suatu Pengantar, Liberty, Yogyakarta, page17.

9 Satjipto Rahardjo, 2000, IImu Hukum, Citra Aditya Bakti, Bandung, page35.

10 Peter Mahmud Marzuki, 2012, Pengantar IImu Hukum, Edisi Revisi, Kencana Prenada Media Group, Jakarta, page209-210. 
the above issues, legal events related to the juridical review of the role of a notary in the draft of the sale and purchase agreement to support national development, in particular the making of the land purchase agreement as the central issue in this study, are then broken down into three sub-issues of law, other:

1. How is the Notary's Role in Establishing a Deed of Sale and Purchase Agreement on Land to Support National Development?

2. What are the Constraints and Solutions in Making the Sale and Purchase Agreement to Support the National Development?

\section{B. Research Methods}

The method of research in legal science is called the legal research method. According to Ronny Hanitijo Soemitro, legal research methods have certain characteristics in which as its identity, because the science of law can be distinguished from other sciences. ${ }^{11}$ Peter Mahmud Marzuki said that legal research is conducted to generate arguments, theories or new concepts as prescriptions in solving the problems encountered. The expected answer is right, appropriate, inappropriate, or wrong. In every legal study contains value. ${ }^{12}$ The type of legal research used in this legal research was juridical-normative research. According to Peter Mahmud Marzuki, a juridical-normative study is a process of finding the rule of law, legal principles, and legal doctrines to address the legal issues faced with prescriptive or ostensible characters. ${ }^{13}$ The legal issue in this research is the juridical notary's role in making the sale and purchase agreement to support the national development.

\section{Discussion}

1. Notary's Role in Establishing Deed of Sale and Purchase Agreement on Land to Support National Development

National development is a series of sustainable development efforts

\footnotetext{
11 Ronny Hanitijo Soemitro, 1990, Metodologi Penelitian Hukum dan Jurimetri, Ghalia Indonesia, Jakarta, page9.

12 Peter Mahmud Marzuki, 2005, Penelitian Hukum, Kencana Prenada Media Group, Jakarta, page35.

13 Ibid.
}

covering all aspects of community life, nation and state, to carry out the task of realizing national goals as formulated in the Preamble of the Constitution of the State of the Republic of Indonesia Year 1945. The series of development efforts contain the ongoing development activities, by raising the level of people's welfare from generation to generation. Implementation of such efforts is done in the context of meeting the needs of the present without compromising the ability of future generations to meet their needs. ${ }^{14}$

Although a Notary is not a state official receiving state salaries and facilities, a Notary is a part of the bureaucracy authorized by the State to make an authentic deed no exception to the PPJB (Sale and Purchase Binding Agreement) deed. The engagements in the traffic of life in the society need important role of Notary especially the economic transaction of land sale and purchase. The contribution of the Notary's role to addressing national development and national resilience is not a wishful thinking.

Notary in carrying out his duties must carry out his position with full responsibility and appreciate all dignity of his position and with the skills that exist in a notary, the notary serves the interest of the public who asks his services, and always the notary must obey the provisions of the Law, ethics, order a notary must be followed by awareness of working independently, honestly, impartially and executed with full sense of responsibility. In performing his duties as a professional, he has good integrity and morals. A notary performs his duties of office only in one office without also permitted to use intermediaries and do educate the nation. Therefore, it is also demanded by a notary in his duty to provide services to the public who need services to provide legal counseling in order to achieve a high legal awareness in society, so that the public realize and

14 General explanation of UU No. 17 Year 2007. 
live their rights and obligations as a citizen and a member of society. ${ }^{15}$

The scope of Notary is indeed in the realm of private law (civil law) but it cannot be denied that the making of the Deed PPJB (Sale and Purchase Binding Agreement) can touch the public legal domain because sometimes it not only involves individual community as the parties but also involves between individual and government. As an example of land acquisition for the public interest is it can occur between the government as a legal entity to conduct sale and purchase transactions by first binding the landowners through the Deed PPJB (Sale and Purchase Binding Agreement). Logical consequence, Notary as the caretaker of the profession becomes an active central actor in accordance with his authority in making deed beneficial for the community to create justice and prosperity in national development.

Notary has a role in making the Deed of PPJB (Sale and Purchase Binding Agreement). Legal ties to bind the parties' engagement in the form of a PPJB deed which it can be used as a perfect proof when one of the parties pledges (lost) through a lawsuit in court. In other words, the Deed of PPJB provides legal protection for the parties. The Deed of PPJB relates to land moving from Article 15 UUJN paragraph (2) UUJN, however it must pay attention to formal and material aspects. PPJB Deed contains Object Sale and Purchase Bonds, Obligations Seller and Buyer, and Contents can refer to Content PPJB can refer to the provisions of Decree of the Minister of Public Housing No. 09 / KTPS / M / 1995 concerning Guidance on Sale and Purchase of House. Notary is not allowed to make the Power of Attorney to Sell in the Deed of PPJB as opposed to some Supreme Court jurisprudence and Instruction of Minister of Home Affairs Number 14 year 1982

15 Ignatius Ridwan Widyadharma, 1996, Etika Profesi Hukum, Badan Penerbit Universitas Diponegoro, Semarang, page133-134. concerning Prohibition of Use of Absolute Power as Land Transfer. Deed PPJB is one means to access justice and national welfare because the making of the Deed PPJB can touch the public legal domain because sometimes not only involve individual community as a party but also involves between individual and government. National development will be realized if the goal of law is achieved. The purpose of law is nothing but creating peace.

National development will be realized if the goal of law is achieved. The purpose of law is nothing but creating peace. Citing the opinion of Peter Mahmud Marzuki by referring to the last part of the Hammurabi Code that lived \pm 2000 years $\mathrm{BC}$ as follows:

"... in my bosom I have carried the people of the land of Shum and Accad, they have become abundantly rich under my guardian spirit, I bear their charge in peace and by my profound wisdom I protect them. That the Strong may not oppress the weak and so to give justice to the orphan and the widow, I have inscribed my precious word on my monument ..."

From the above quotation it is clear that in the state of peace there is abundance, which strongly does not oppress the weak, who entitled to really get his rights, and the existence of legal protection for society. ${ }^{16}$ The law must be able to create peace, not just discipline. In a situation of peace the law protects the interests of man both materially and immaterial from harmful acts. ${ }^{17}$

In the Islamic concept embodied in the Medina Charter made by Prophet Muhammad S.A.W as stated by Jamalludin Sarur, a professor of Islamic History that the Medina of Prophet Mohammed gave the same rights and obligations to the Muhajirin, Ansor and the Jews. They live in harmony and peace in one state 16 Ibid.

17 Ibid, pg. 129. 
of Medina. And Muhammad Khalid, a historical author of the Prophet, affirms that the most principled content of the harmonious Medina Charter (ummah) regulates an umma with a form of law with the aim of establishing government on the basis of justice, equality, equality of rights to one another. ${ }^{18}$

2. Constraints and Solutions in the Making of Sale and Purchase Act to Support National Development

National development towards national defense, it is especially in the case of the need for land. The other aspects related to land are the defense and security of the territory of the State. Geographically, Indonesia is an archipelago country located between two oceans namely Indian Ocean and Pacific Ocean. Indonesia consists of islands of $+17,504$ islands with an area of 5.8 million $\mathrm{km} 2$ and a coastline of 81,900 $\mathrm{km} 2$. Almost two thirds of Indonesia's territory is waters and one third is land area. Indonesia borders the sea with 10 countries namely Malaysia, Singapore, Philippines, India, Thailand, Vietnam, the Republic of Palau, Australia, Timor Leste and Papua New Guinea. On land, Indonesia is bordered by three countries, namely Malaysia, Papua New Guinea, and Timor Leste with a total length of the land border as a whole reaches 2,914.1 $\mathrm{km}$. Given these geographical conditions, the handling of defense and security issues within the framework of state sovereignty makes a very complex thing when it is associated with maintaining the diversity of national resources as a nation's asset. Likewise with the issue of economic development, improving the quality of human resources and

18 Ahmad Zayyadi, 2013, Sejarah Hukum Konstitutsi Madinah Nabi Muhammad S.A.W. Analisis Charter of Medina dan Relevansinya di Indonesia, Wahana Akademia, Vol. 15 No. 1, April 2013 page86. Lihat, Azizah Y.Al-Hibri, Islamic and American Constitutional Law: Borrowing Possibilities or A History of Borrowing?, Journal of Constitutional Law, Vol. 1: 3, 1999, page512. fostering in other border areas would require more specific treatment, because these areas have different characteristics of the problem. Therefore, defense and security are an integral part of maintaining the unity and integrity of the country in the region. ${ }^{19}$

In Indonesia's border regions, the land is usually owned by indigenous and tribal peoples. There is a weakness in providing legal protection for customary land, the state only acknowledges and respects it only in Article 18B paragraph (1) of the 1945 Constitution, Article 2 Paragraph (4) of BAL and Article 3 of the BAL and its Elucidation and Article 67 Paragraph (1) of Law No. 41 of 1999 on Forestry ("Forest Law"). In the absence of concrete legal products such as written evidence of the existence of an ulayat or customary land title certificate. So, this will complicate the existence of legal relations when the existence of a development in an area that involves stake holders and private. Of course national development towards national defense will be difficult to realize. So in the context of the legal relationship begins with the Engagement as outlined in the Deed of Sale and Purchase Land or Deed PPJB made before the Notary by the parties will be difficult to materialize.

Notary can play a role in the above legal event, namely Notary can play a role of making deed for land that has not been certified in the form of Notary Deed on the Transition of Land Rights. The deed is entitled Release of Rights with Indemnity. The role of this Notary is without disregarding the PPAT function in making land deed due to justification reasons. These reasons include:

a. Under Article 1 jo. Article 7 Notary Position Regulation;

b. Based on Article 2 paragraph (2) and paragraph (3) of Basic Agrarian Law;

19 Nia Kurniati, Op, cit, hal. 101. 
c. Under Article 1457 of the Civil Code.

The content of each article explains that a Notary may make a deed of the right to transfer land rights in accordance with the applicable provisions. ${ }^{20}$

Factors that cause Notary to perform the deed of Disposal of Rights with Compensation, Notary function can replace the function of PPAT in making deed before the Notary and the legal effect of deed which should be made by PPT. The function of Notary replacing the PPAT in the deed is based on their respective functions. Notary can make deeds for land that have not been certified and have been certified. Notary also can make the authentic deed that should be made by PPAT to the land. Reasons for justification such as the master certificate have not been broken up or the land purchased is still absentee land. Legal consequences arising from a deed that should be drawn up by the PPAT but made before a Notary is the land is still a legal land, but if the Deed made deviate from the applicable provisions, it resulted in the deed is invalid because it contains legal defect. ${ }^{21}$

To be able to improve Notary's function as PPAT for deed of land rights transition, it is expected that the public should be able to utilize Notary's function in order to obtain authentic authentication tool. However, the Notary must remain cautious when receiving the evidence given by the interrogators to make the deed he made does not contain legal defects.

Indonesia's border areas are usually owned by indigenous peoples whose land can be categorized as absentee land. It can be transferred land rights with compensation in the form of deed made before the Notary. In this context, it can be included in the National Development Program towards national defense where

\footnotetext{
20 http://herman-notary.blogspot.co.id/2009/03/fungsinotaris-dalam-pembuatan-akta.html, accessed on 15 March 2017

21 Ibid.
}

the government needs the land in land procurement projects for public interest such as toll roads or private sector that require industrial land. All this is done with due regard to local cultural customs, keep the ecosystem both animals and plants that are supported by a good environmental impact analysis

Obstacles in making the Deed PPJB (Sale and Purchase Binding Agreement) include land status, such as, the status of customary land, State land and land letter $\mathrm{C}$ so as to violate the object of agreement as regulated in Article 1320 of the Civil Code. Furthermore, the action is not allowed as intended in Article 85 UUJN. Notary has its own working area in 1 (one) province and place in 1 (one) city or regency in that province as stipulated in Article 18 paragraph (1) UUJN related to Article 19 paragraph (2) UUJN which affirm Notary not authorized to regularly run a position outside his position. It then apply the principle of relative competence of the rationed loci (place) where the Notary is entitled to make deed in accordance with the legal domicile of Notary. If the ratione loci (place) is violated, then the Notary may be subject to sanctions as stipulated in Article 1868 and Article 1869 Civil Code. In practice it is often encountered where the parties make a land purchase agreement in the form of under hand deed, the legal consequences is not having perfect legal force. The worst thing is one party denied for having committed with the other parties. The duties and authorities of Notary are in the circle of legal system consisting of legal structure, legal substance and legal culture. In carrying out its profession, Notary under Notary's legal Structure is within the scope of Notary Organization of Indonesian Notary Association (INI). The supervision of the Notary is conducted by the Ministry of Law and Human Rights (Kemenkumham (Ministy of Law and Human Right)) delegated to the Regional 
Supervisory Board (MPD), the Regional Supervisory Board (MPW) and the Central Assembly (MPP). In addition, it also involves various institutions such as Police, Attorney, Land Board, Courts and institutions both government and private. Enforcement of legal substance for the Notary is guided by the legislation such as UUJN, Civil Code, KUHD, and so forth. The legal culture is the values that are deposited in the Notary's Code of Conduct as the signs in running the Notary profession. This is a necessity that the structure, substance and culture of law greatly affect the position of Notary in carrying out his profession.

To master or to be controlled here means that it is possessed physically in the sense of being tilled inhabited. However, it is not necessarily, he is the owner, which means he control the land to be used in a physical sense, also in a juridical sense. ${ }^{22}$ it also has civil aspect and public aspect. Land tenure here refers to the right of juridical and physical mastery of civil rights.

Juridical control is based on rights protected by law and generally authorizes the right holder to physically control the land in custody. But there is also a juridical mastery that even authorizes control of physically abused land. In fact its physical control is done by others. For example, if the land is leased to the other party and the tenant control it physically. Or the land is physically controlled by others without rights. In this case the landowner under his juridical tenure is entitled to claim the physical relinquishment of the land to him. In the law of the land, it is also known as juridical control that does not give authority to control the land physically. The creditor of the land title holder has the right of juridical control over the land to be used as collateral, but the physical control remains with the land owner.

22 Boedi Harsono, 1999, Hukum Agraria Indonesia, Sejarah Pembentukan UUPA, Isi, dan Pelaksanaan, Djambatan, Jakarta, page5.

\section{CONCLUSION}

\section{Summary}

1. The role of a notary in the making of a land purchase agreement to support the National Development rests with the legal relation to bind the parties' engagement in the form of a PPJB (Sale and Purchase Binding Agreement) (Sale and Purchase Binding Agreement) deed which can be used as a perfect proof when one of the parties pledges (wanprestasi/ lost) through lawsuit in court. In other words, the Deed of PPJB provides legal protection for the parties. The Deed of PPJB relates to land moving from Article 15 UUJN paragraph (2) UUJN, however it must pay attention to formal and material aspects. Deed of PPJB contains Object Sale and Purchase Bonds, Obligations Seller and Buyer, and Contents can refer to Content PPJB can refer to the provisions of Decree of the Minister of Public Housing No. 09 / KTPS / M / 1995 concerning Guidance on Sale and Purchase of House. Notary is not allowed to make the Power of Attorney to Sell in the Deed of PPJB as opposed to some Supreme Court jurisprudence and Instruction of Minister of Home Affairs Number 14 year 1982 concerning Prohibition of Use of Absolute Power as Land Transfer. Deed of PPJB is one means to access justice and national welfare because the making of the Deed PPJB can touch the public legal domain because sometimes not only involve individual community as a party but also involves between individual and government. National development will be realized if the goal of law is achieved. The purpose of law is nothing but creating peace.

2. There are obstacles in making the Deed of PPJB such as the status of land, among others, the status of customary land, State land and land 
letter $\mathrm{C}$ so as to violate the object of agreement as regulated in Article 1320 of the Civil Code. Furthermore, the action is not allowed as intended in Article 85 UUJN. Notary has its own working area in 1 (one) province and has a domicile in 1 (one) city or regency in that province as stipulated in Article 18 paragraph (1) UUJN related to Article 19 paragraph (2) UUJN which affirm Notary not authorized to regularly run a position outside his position. Then apply the principle of relative competence of the ratione loci (place) where the Notary is entitled to make deed in accordance with the legal domicile of Notary. If ratione loci (place) is violated, then the Notary may be subject to sanctions as stipulated in Article 1868 and Article 1869 Civil Code. In practice it is often encountered where the parties make a land purchase agreement in the form of under hand deed, the legal consequences of not having perfect legal force, if one party denied having committed the engagement unless the party acknowledges it. The duties and authorities of Notary are in the circle of legal system consisting of legal structure, legal substance and legal culture. In carrying out its profession, Notary under Notary's legal Structure is within the scope of Notary Organization of Indonesian Notary Association (INI). The supervision of the Notary is done by the Ministry of Law and Human Rights (Kemenkumham(Ministryof Law and Human Right)) delegated to the Regional Supervisory Board (MPD), the Regional Supervisory Board (MPW) and the Central Assembly (MPP). In addition, it also involves various institutions such as Police, Attorney, Land Board, Courts and institutions both government and private. Enforcement of legal substance for the Notary is guided by the legislation such as UUJN, Civil Code, KUHD, and so forth. The legal culture is the values that are deposited in the Notary's Code of Conduct as the signs in running the Notary profession. A necessity that the structure, substance and culture of law greatly affect the position of Notary in carrying out his profession.

3. Notary can perform legal findings as outlined in the Deed of PP JB originating from concrete eve nts ie the wishes of the parties. In the notaries deed, the Notary should conduct a careful examination of the parties' wishes whether they are contrary to applicable law or not. This will affect every making of the Deed of PPJB in accordance with the subjective requirements and objective conditions of an agreement and has fulfilled the material nerve and formal requirements as regulated in UUJN. Therefore, the deed cannot be requested for cancellation by the injured party to the court on the basis of Article 1365 of the Civil Code and does not close the possibility of being charged under Artic le 242 of the Criminal Code, Article 263 paragraph (1) of the Criminal Code, Article 372 paragraph (1) of the Criminal Code; 21 of 2008 concerning Sharia Banking, Article 264 paragraph (1) of the Criminal Code, Article 5 paragraph (1) of Law Number 8 Year 2010 concerning Prevention and Eradication of Money Laundering Criminal Act (TPPU). The role of Notary is central in national development towards national resilience, although rarely realized by the community considering the task and authority only make authentic deed. 


\section{BIBLIOGRAPHY}

Bernhard Limbong, 2012, Hukum Agraria Nasional, Margaretha Pustaka, Jakarta;

Boedi Harsono, 1999, Hukum Agraria Indonesia, Sejarah Pembentukan UUPA, Isi, dan Pelaksanaan, Djambatan, Jakarta , 2012, Hukum Agraria Indonesia, Djambatan, Bandung;

Darwin Ginting, 2010, Hukum Kepemilikan Hak Atas Tanah Bidang Agribisnis, Ghalia Indonesia, Jakarta;

Ignatius Ridwan Widyadharma, 1996, Etika Profesi Hukum, Badan Penerbit Universitas Diponegoro, Semarang;

Nia Kurniati, 2012, Laporan Akhir Tim Pengkajian Hukum Tentang Pengelolaan Tanah Negara Bagi Kesejahteraan Rakyat, Pusat Penelitian dan Pengembangan Sistem Hukum Nasional Badan Pembinaan Hukum Nasional Kementerian Hukum dan Hak Asasi Manusia RI, Jakarta;

Peter Mahmud Marzuki, 2005, Penelitian Hukum, Kencana Prenada Media Group, Jakarta; Jakarta; 2012, Pengantar Ilmu Hukum, Edisi Revisi, Kencana Prenada Media Group,

Rachmadi Usman, 2009, Hukum Perwakafan Di Indonesia, Sinar Grafika, Jakarta;

Ronny Hannitijo Soemitro, 1990, Metodologi Penelitian Hukum dan Jurumetri, Ghalia Indonesia, Jakarta;

Satjipto Rahardjo, 2000, Ilmu Hukum, Citra Aditya Bakti, Bandung;

Sudikno Mertokusumo, 2014, Penemuan Hukum Sebuah Pengantar, Edisi Revisi, Cahaya Atma Pustaka, Yogyakarta; 